\title{
Prevalence and impacts of fall army worms (Spodoptera frugiperda) on maize (Zea mays) production and productivity in Ethiopia
}

\author{
Atnafu Wondimu ${ }^{1,2^{\star}}$, Beyene Petros ${ }^{1}$, Zemede Asfaw $^{3}$ and Yitbarek Woldehawariat ${ }^{4}$ \\ ${ }^{1}$ Department of Microbial, Cellular, and Molecular Biology, College of Natural and Computational Sciences, \\ Addis Ababa University, Addis Ababa, Ethiopia. \\ ${ }^{2}$ Department of Food Science and Applied Nutrition, Addis Ababa Science and Technology University, Addis Ababa, \\ Ethiopia. \\ ${ }^{3}$ Department of Plant Biology and Biodiversity Management, Addis Ababa University, Addis Ababa, Ethiopia. \\ ${ }^{4}$ Department of Zoological Sciences, Addis Ababa University, Addis Ababa, Ethiopia.
}

Received 30 October, 2020; Accepted 24 May, 2021

\begin{abstract}
Maize is a key determinant of food security, mainly grown as subsistence in Ethiopia. It was introduced to Ethiopia in 1600's from Mexico. Food security of Ethiopia is threatened from time to time due to crop diseases and pests. One of these is fall armyworms (Spodoptera frugiperda, J.E Smith; lepdoptera, Noctudea), which is a recently arrived American origin insect pest. As best contributor of Ethiopian economy and social development, maize is being seriously threatened by fall armyworms (FAWs). Maize production stands second in Ethiopia (20.2\%) next to teff $(34.2 \%)$ in terms of the land allotted. However, in terms of productivity maize stands first $(45.5 \%)$ in relation to teff $(29.9 \%)$, sorghum $(27.2 \%)$, and wheat $(26.2 \%)$. The productivity of maize is suppressed by FAW infestation very significantly (PS 0.05) in the previous three years after its arrival to Ethiopia in 2017. The rate of infestation ranges from $1.7-34.5 \%$ in the past three successive years. According to our results, maize infested by FAW in the past three successive years at regional states levels is shown to devastate produces up to $71 \%$, with the four top infested regions being Gambella (70.4\%), Afar (61.6\%), Benshangul Gumuz (11.8\%), and SNNPRS (10.7\%). Health and environmental risks associated with the use of synthetic pesticide chemicals are very profound; hence, environmentally friendly organic based controlling methods of pests with minimum risks such as the use of botanicals, and biological controls are strongly recommended.
\end{abstract}

Key words: Fall armyworm, pest, Ethiopia, maize, productivity.

\section{INTRODUCTION}

Maize (Zea mays L.) is a staple crop in Ethiopia which is a member of grass family, Poaceae (Das et al., 2010; Abu, 2015). It was known to be originated in Mexico, and introduced to Ethiopia in 1600's (Gemechu et al., 2016). Nowadays more than 9 million smallholder farmer households grow maize in Ethiopia and the country is

*Corresponding author. E-mail: atnafu29@gmail.com.

Author(s) agree that this article remain permanently open access under the terms of the Creative Commons Attribution License 4.0 International License 
reported as second highest producer of maize in Africa next to South Africa (EIAR et al., 2010). It is a key determinant of food security, mainly grown as a subsistence crop in the mid-altitudes (1500-2000 m above sea level) in southern, south-central, and southwestern parts of Ethiopia (Abate et al., 2015; EIAR et al., 2010; Kebede et al., 1993). Ethiopia has doubled its production and productivity of maize in the recent past less than two decades (Gemechu et al., 2016) with the current yield estimated to be more than 3 metric tons per hectare (Abate et al., 2015).

Maize is easily adaptable to all agro-ecological zones and grown in the lowlands, mid-altitudes and the highland regions (Misgana et al., 2015; Bekeko, 2013; Kebede et al., 1993). It is very important in Ethiopia's food security more than any other crops (Abate et al., 2015; Seyoum et al., 2010). Great genetic variability and adaptability to diverse regions, farming systems, and consumer preferences of different socio-economic backgrounds is typical to maize crops (Misgana et al, 2015; Abile and Alemayehu, 2014). Ethiopia's white non-genetically modified organic maize is more preferred in neighboring markets though it is most affected by pests relatively (Abate et al., 2015). Demand for maize productivity need to be increased significantly in Ethiopia in the future (Abate et al., 2015). Productivity is estimated to increase almost double of the current trend in the future until 2050 (Rosegrant et al., 2008). The popularity of maize in Ethiopia is due to its value as food for human and animal fodders (Ashenafi, 2010). Approximately 88\% of maize produced in Ethiopia is consumed as food, both as green and dry grain (Misgana et al., 2015; ATA, 2014). Maize is also used as sources of fuel for rural people mainly in the four major producing regions of the country, Oromia, Amhara, SNNPR, and Tigray (Abate et al., 2015).

The recent most common diseases and pest infestations of maize originate from nematode parasites, fungal parasites, fall armyworms, and maize lethal necrosis (CIMMYT, 2015; USDA, 2017). The fall armyworms (Spodoptera frugiperda) affect more than 80 crops; but prefer maize more than any of them as host (FAO, 2017; ACAPS, 2019). Cultural controls such as crop rotation, organic amendments, and biological controls have been tried to manage maize parasites; however, none of these have been significantly effective in extensive productions (Nicol et al., 2011). Food security of Ethiopia is threatened from time to time due to crop diseases and pests including the fall armyworms (ACAPs, 2019).

The fall armyworm (FAW; S. frugiperda (J.E Smith); Le pidoptera, Noctudea), which arrived Africa in early 2016, is nowadays a major threat to the productivity improvements of maize in Ethiopia (Prasanna et al., 2018). The FAW spread faster causing significant damages on maize crops in the major maize producing regions of Ethiopia after it was detected lately in 2017 (FAO, 2017).
This study is aimed at surveying the prevalence of the fall armyworms by analyzing the documents from national level reports of Ministry of Agriculture, reviewing recent literatures, and analysis of raw data from different regions in Ethiopia; and also data from published resources focusing on maize infestation of fall armyworms in Ethiopia.

\section{Objectives}

\section{General objective}

To evaluate the prevalence of fall armyworms and its impacts on maize productivity in Ethiopia.

\section{Specific objectives}

i) To determine the productivity rate of maize as staple crop in Ethiopia.

ii) To measure the distribution trends of FAWs in different regions of Ethiopia.

iii) To estimate the economic and health impacts based on percept yield reduction and percept of hazardous chemical pesticides used per annum.

iv) To recommend best future controlling options against the rampaging pest, FAWs.

\section{METHODOLOGY}

\section{Study design}

We used a case report based observational design in this study. The primary data were obtained by interviewing experts; and from archived documents collected from the reports of Ministry of Agriculture (MOA), Plant Protection Department, Ethiopia. Successive official reports from the regional states agricultural sectors where maize is produced were reviewed as major data sources. The raw data were reprocessed by authors own calculations and analyzed by applying statistical techniques.

\section{Geographic ranges of the data collection}

The study was conducted in Ethiopia, focusing on major maize producing regions. Eight maize producing regional states of Ethiopia, namely SNNPRS, Amhara, Tigray, Oromia, Gambella, Etio-Somalia, Afar, and Beshangul Gumuz were the basis for the study. Annual and quarterly reports from the regional states regarding fall armyworm outbreaks, and its impacts on the maize productivity were assessed. The archived documents of the past reports in the Plant Protection Department, Ministry of Agriculture were used as data sources. The experts from the Plant Protection Department, Ministry of Agriculture were also interviewed as sources of data for our study.

\section{Data collection and analysis methods}

All data obtained from Ministry of Agriculture, Plant Protection Department were collected face to face based on the agro-ecology of maize production in Ethiopia. Some data were collected by 


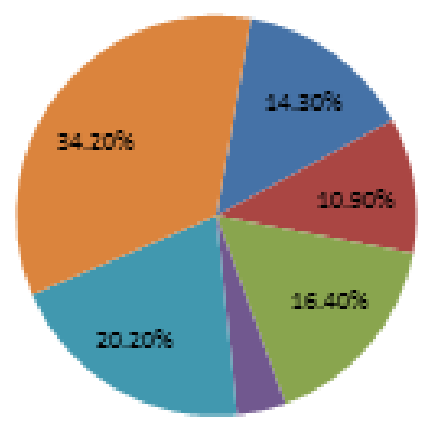

Whe at
Barely
Sorghum
Millet
Maize
Teff

Figure 1. Relative percent of land allotted for crops (calculated by authors from different data).

interviews made with experts, and others from reports of the respective regions in agricultural sectors. The data used in the study were collected from September, 2017 to February, 2020. The prevalence rate of fall armyworms was evaluated based on three years reports from the eight different maize producing regional states of Ethiopia.

The study results were presented using tables, graphs and charts. The tabulated data were analyzed using SPSS software version 20.

\section{RESULTS AND DISCUSSION}

\section{Annual production and consumption estimates of maize in Ethiopia}

Maize productivity in Ethiopia was reported to have been doubled between the years 1990 to 2017 (Abate et al., 2015; ACAPS, 2019). Annual yield gain rose to $68 \mathrm{~kg} / \mathrm{ha}$ in the periods before introduction of FAW (Abate et al., 2015). Ethiopia is the second producer of maize in SubSaharan African countries next to South Africa. Research results show that maize plays a central role in Ethiopia's food security (EIAR et al., 2010; ACAPs, 2017). Annual production and consumption estimates from our result conform to most of such previous research results (Figure 1).

Increase in productivity is attributable to increase in demand (Rosegrant et al., 2008). According to our results, highest portion of land is allotted for Teff (34.2\%). Maize $(20.2 \%)$ is second in ranking in terms of the total land it holds (fig.1); however in terms of productivity, maize relatively occupies the first rank (45.5\%). Hence from the obtained results, we can conclude that the demand for maize in Ethiopia is still very high relative to other many cereals next to Teff. Trends of maize productivity revealed that it increased step-wise each year between 2004 and 2015 due to the better productivity, and shifting of the agricultural occupation which occurred from sorghum and teff to maize production (Abate et al., 2015).

According to our results (Figure 2), in terms of productivity maize is the most productive relative to five top cereals in the country if not attacked by diseases and pests. The result shows that it is greater than any of the single cereal crop that agrees to the past few years' reports (FAO, 2017; Abu, 2015). This result is comparable to the results of many other researches on maize in Ethiopia (Harold, 2015; Abate et al., 2015; EIAR et al., 2010). It can be deduced from the results that progressive maize productivity trends shows potential increase in both economic advantage and social contributions that conforms to reports by EIAR et al. (2010).

Our results from the past three years data shows that annual productivity of maize is significantly higher $(P<0.05)$ than any other mono-crops such as wheat, barely, sorghum, millet, and teff in Ethiopia (Figure 2). However, threats that can suppress the productivity of the cereals due to varieties of pests, and nematode infections are among anticipated future challenges (Assefa and Ayalew, 2019; Tsedaley and Adugna, 2016; Mahuku et al., 2015; Abile and Alemayehu, 2014).

\section{Progressive incidences of fall armyworms on maize crops in Ethiopia}

Infestations of maize by FAW lead to complete losses of products that affected both crop producers and consumers rendering them to serious food security problems (EIAR, 2010; EARO, 2001). Our results (Table 1) shows that some regions of Ethiopia such as EthioSomalia in 2018/19 (99.13\%), and Afar (59.22\%) have been affected seriously, which rendered them to be severely food insecure in the years. This results conforms to the reports of food security in the regional states in the years mentioned (ACAPs, 2019).

According to this result, the outbreak of fall army worms is progressive in successive years; and it looks a major threat to the country as to the fast spreading character of the pests (FAO, 2017). It was known that since its introduction to Africa in March 2017, the FAWS affected the country's productivity most significantly $(P<0.05)$ in terms of crop product reduction.

\section{Comparative yield reduction of maize by FAW in different regional states of Ethiopia}

Yield reduction due to the pests and FAWs is mainly attributable to the resistance buildup of the pests to the chemical insecticides (Bezuidenhout and Nunkumar, 2017). Significant amounts of maize yield reduction occur by different plant pests in Ethiopia (Tsedaley and Adugna, 2016; Mahuku et al., 2015; Bekeko, 2013). Our results show that there is relatively notable yield loss (60$70 \%$ ) by the infestation of the fall armyworms (S. frugiperda) in the past three successive years in the maize producing regions of Ethiopia (Table 2). 


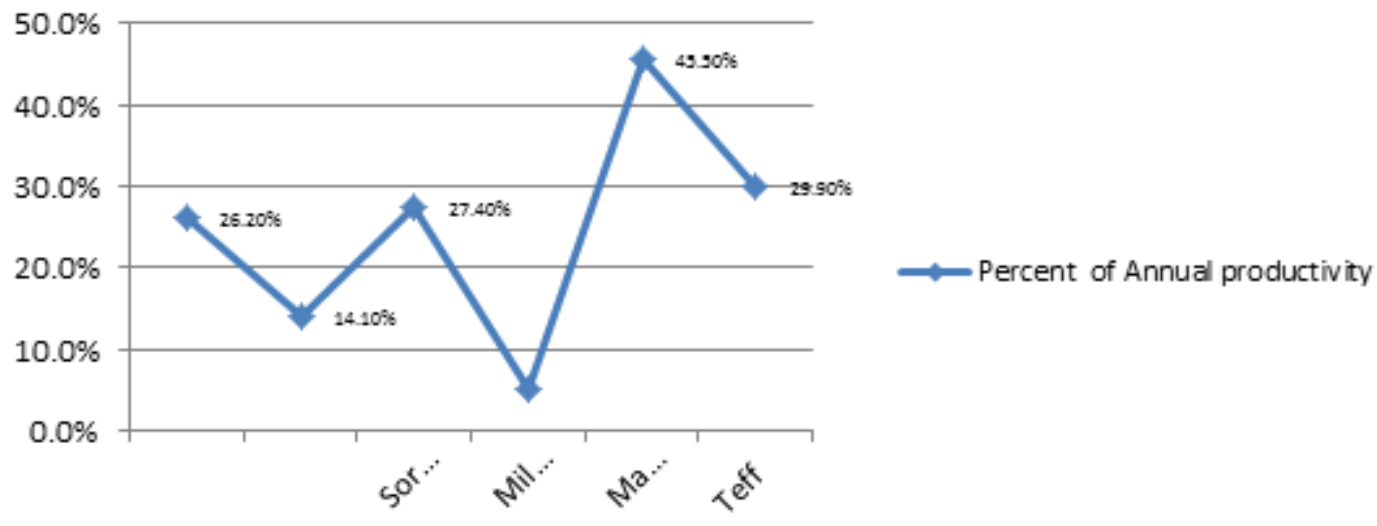

Figure 2. Percent of annual crops productivity.

Table 1. Maize infestation by fall armyworms in different regional states of Ethiopia from 2017 to early 2020 .

\begin{tabular}{|c|c|c|c|c|c|c|}
\hline Region & $\begin{array}{l}\text { Total land affected } \\
\text { in the Year 2017/18 } \\
\text { (ha) }\end{array}$ & $\begin{array}{c}\text { Percent } \\
\text { of infestation }\end{array}$ & $\begin{array}{l}\text { Total land affected } \\
\text { in the year 2018/19 } \\
\text { (ha) }\end{array}$ & $\begin{array}{l}\text { Percent of } \\
\text { infestation }\end{array}$ & $\begin{array}{c}\text { Total land affected } \\
\text { in the Year 2019/ } \\
20 \text { (ha) }\end{array}$ & $\begin{array}{c}\text { Percent } \\
\text { of infestation }\end{array}$ \\
\hline SNNPRS & $82,190.43$ & 17.34 & $200,414.37$ & 23.1 & $44,962.83$ & 9.68 \\
\hline Oromia & $212,286.3$ & 29.17 & $472,761.20$ & 25.2 & $909,405.27$ & 24.85 \\
\hline Amhara & 67,404 & 15.5 & $683,000.00$ & 18.26 & $106,093.50$ & 8.75 \\
\hline Tigray & 1,396 & 1.7 & 6048.48 & 2.1 & 23484.60 & 9.58 \\
\hline Benshangul Gumuz & $20,747.3$ & 65.8 & 36935.91 & 9.55 & 26735.00 & 3.98 \\
\hline Gambella & 3,134 & 34.7 & 13704.90 & 51.18 & 14780.00 & 16.77 \\
\hline Afar & - & - & 4132.00 & 59.22 & - & - \\
\hline Ethio-Somalia & - & - & $25,770.00$ & 99.13 & - & - \\
\hline
\end{tabular}

Source: MOA, Ethiopia.

Assefa and Ayalew (2019) noted that fall armyworm ( $S$. frugiperda) contributes to the low productivity of maize in Ethiopia since its introduction in February 2017. Our results also revealed that there is significant yield losses in maize productivity $(\mathrm{P}<0.05)$ due to this pest fall armyworms (Table 2). The most affected regional states are Gambella (70.4\%), Benshangulgumuz (60.7\%), Afar $(61.6 \%)$, and SNNPRS (12.6\%). It is true that the fall armyworms became the most droughts inducing pest well established in the country and can suppress productivity very significantly up to complete loss of the produces.

Health and economic impacts due to the use of synthetic pesticide chemicals against FAWs in Ethiopia

\section{Estimated health Impacts due to use of synthetic insecticides}

Use of synthetic chemical pesticides was found to be significantly risk associated, harming the health of both human, and animals besides the damage to the environments (Midega et al., 2018). There is urgent need for more suitable and cost-effective measures especially easily locally adaptable control methods for smallholder farmers in countries such as Ethiopia (FAO, 2019).

According to our results, maize as staple food crop is seriously threatened by the fall armyworm; thus, use of traditional methods become more impacted in controlling the infestation and loss than that of using synthetic chemicals (Table 3 ). Higher external inputs such as organophosphates can have profound negative impacts on the health of the farmers and the environment (Karanth and Pope, 2000). Knowledge limitation of using the chemicals and also lack of special cares can be aggravating factors that can be added to the severity of the effects of the synthetic chemical pesticides. Effective traditional techniques and biodegradable botanical pesticides are more recommendable than the use of hazardous synthetic chemicals.

The risks associated to the frequent use of chemical ins ecticides are significant in human health, animal health, and environmental safety (Bezuidenhout and Nunkumar, 
Table 2. Yield reduction of maize by infestation of FAWs in Ethiopia from 2017 to early 2020.

\begin{tabular}{lcccc}
\hline Regional state & $\begin{array}{c}\text { Estimated yield reduction } \\
\text { (Loss in hectares)/2017/18 }\end{array}$ & $\begin{array}{c}\text { Relative } \\
\text { percent }\end{array}$ & $\begin{array}{c}\text { Estimated yield reduction } \\
\text { (loss in hectares)/2019/20 }\end{array}$ & $\begin{array}{c}\text { Relative } \\
\text { percent }\end{array}$ \\
\hline SNNPRS & $10,335.1$ & 12.6 & $21,280.1$ & 10.7 \\
Oromia & $94,992.3$ & 44.8 & $20,248.8$ & 4.8 \\
Amhara & 21,164 & 31.4 & 4923.8 & 4.0 \\
Tigray & 23.9 & 1.8 & 164.9 & 2.8 \\
Benshangul Gumuz & 12599.3 & 60.7 & 4341 & 11.8 \\
Gambella & 244 & 7.8 & 9643.9 & 70.4 \\
Afar & Not reported & - & 2545 & 61.6 \\
\hline
\end{tabular}

Source: Author's calculation using data from Ministry of Agriculture; Plant Protection Directorate (from 2017 to early 2020).

Table 3. Relative use of chemical pesticides and traditional organic methods to control FAWs in the past few years in seven regional states of Ethiopia.

\begin{tabular}{clcccc}
\hline S/N & Regional state & $\begin{array}{c}\text { Chemicals pestici } \\
\text { des used (\%) } \\
\mathbf{2 0 1 7 / 1 8}\end{array}$ & $\begin{array}{c}\text { FAWs controlled by traditi } \\
\text { onalmethods/with no che } \\
\text { micals (\%) 2017/18 }\end{array}$ & $\begin{array}{c}\text { Chemicals insecticid } \\
\text { es used (\%) 2019/20 }\end{array}$ & $\begin{array}{c}\text { FAWs controlled by traditi } \\
\text { onalmethods/with no che } \\
\text { micals (\%) 2019/20 }\end{array}$ \\
\hline 1 & SNNPRS & 44.7 & 41.2 & 39.7 & 49.7 \\
2 & Oromia & 36.9 & 28.9 & 44.9 & 60.1 \\
3 & Amhara & 35.5 & 56.3 & 36.6 & 59.5 \\
4 & Tigray & 22.3 & 80.1 & 15 & 82.4 \\
5 & Benshangul Gumuz & 7.4 & 33.2 & 7.6 & 80.7 \\
6 & Gambella & 22.9 & 22.1 & 29.6 & - \\
7 & Afar & 34.1 & 21.2 & 29.1 & 9.3 \\
\hline
\end{tabular}

Source: Author's calculation using data from Plant Protection Directorate, Ministry of Agriculture.

Table 4. Comparative economic impacts due to anti-pest chemicals in the past three successive years.

\begin{tabular}{ccccc}
\hline S/N & Crop year & $\begin{array}{c}\text { Crop land affected and sprayed } \\
\text { with artificial insecticide (ha) }\end{array}$ & $\begin{array}{c}\text { Estimated cost of insecticide/in } \\
\text { dollars/* }\end{array}$ & Relative percent \\
\hline 1 & $2017 / 18$ & $387,158.1$ & $3,629,714.4$ & 17.1 \\
2 & $2018 / 19$ & $754,111.5$ & $8,809,479.7$ & 41.4 \\
3 & $2019 / 2020$ & $1,185,259.9$ & $8,821,539.7$ & 41.5 \\
\hline
\end{tabular}

${ }^{*}$ Cost estimation is based on least unit prices of Diazinon, chloropyrifos, and malathion, and other agriculture pesticide chemicals released on website by manufacturers: kingquenson.com Ad·www.kingquenson.com/. Accessed on April12, 2020.

2017). Use of synthetic chemicals as crop protection mechanism can even be life threatening by causing acute and chronic toxicities that can most probably result in significant mortality cases (Christensen et al., 2009; Kamrin, 1997). According to our results, the use of synthetic chemicals such as malation, chloroprifos, and diazinon is significant $(P \leq 0.05)$, in percent rages from 15$82.4 \%$ at different regional states of Ethiopia.

\section{Economic impacts due to use of chemical pesticides}

According to our results, the FAWs outbreak has shown significant impacts on the smallholder farmers' economy in terms of crop product losses (Table 4). The FAWs infestation impacts not only the individual farmer's economy but also at national economy in general. The economic loss due to damage of the fall armyworms is noted in terms of both injuries by the pest and loss of money to buy the pesticides (Prasanna et al., 2018). Economic loss due to FAWs infestation is most significant $(P \leq 0.05)$ in Ethiopia since its confirmed spread in the country in late 2017 quantitatively ranges from 17.1 to $41.5 \%$ (Table 4). Emphases on the control support of the pest especially by the humanitarian aids such as FAO shifted from the FAWs to desert locusts especially 2018 onwards, which seem to exacerbate the spread of the pest across the country. 


\section{Conclusion}

The fall armyworms continued affecting maize crops in Ethiopia, which is the non-abandonable staple food of the Ethiopian people. The progressive occurrences of the pest revealed that this pest can potentially be well established in the country. The fall armyworm is notably prevalent thoroughout the country among maize producing regions by now after its arrival in late 2017. As FAW is polyphagous (live on several hosts), infesting more than 80 crops, all of which are well grown in Ethiopia, it is expected to spread further, damaging most of the food crops including vegetables. Yield reduction of maize due to fall armyworm outbreak was very serious that it plunged some regions of Ethiopia into food insecurity. The use of synthetic chemicals especially organophosphates in Ethiopia for the controlling of fall armyworms (S. frugiperda J.E Smith) such as chloropyrifos, malathion, and diazinon severely harmed humans, and animals health, and also the environment. The use of the pesticides is associated with both acute and chronic public health risks; the synthetic chemicals are significantly used in Ethiopia since the introduction of FAWs in late 2017. Economic loss due to FAW infestation is significant on Ethiopians, both individual farmers and at country level in general.

\section{Recommendations}

As the use of synthetic chemicals severely negatively impacted health of both human and animals, it is recommendable to use less harmful and environmentally friendly local botanical based controlling techniques rather than hazardous synthetic organophosphate chemicals. Traditional methods of controlling the pest, FAWs, better encourage relative to chemical pesticides as the knowledge of chemical application among the farmers in Ethiopia is limited, and chemical pesticides can significantly result to adverse health impacts.

The socioeconomic impacts of the pest, fall armyworms is most significant, hence lasting solution for this devastating crop pest must be sought in order to spare the society from the effects. There is no mandatory medical monitoring with laboratory reporting even at least for agricultural workers working with the pesticides that might have resulted in many non-reported morbidity, and mortalities; hence, it is recommendable to devise safety rules and clear guides especially for local farmers, agricultural extension workers, and the other experts in the country who manipulate and handle the pesticides. There must be binding and obligatory legislation that force monitoring of the health of individuals working with the organophosphate pesticide compounds in order to check their health status on scheduled basis. Use of safety facilities and recommendations of precautions to the manipulators of chemicals is limited; hence, both the government and partners have to give special focus to the promotion of biological controls and safe botanical pesticides.

\section{CONFLICT OF INTERESTS}

The authors have not declared any conflict of interests.

\section{ACKNOWLEDGEMENTS}

The authors are grateful to all who contributed in the data collection in completing this research paper. The contribution of Ato Zebdewos Salato (The Director of Plant Protection Department, Ministry of Agriculture, Ethiopia) who passionately helped to get almost all the primary data in the completion of this paper is also appreciated. Authors' gratitude also go to the Academic advisors, Prof. Beyene Petros, Dr. Yitbarek W/hawariat, and Prof. Zemede Asfaw who commented on the draft manuscripts, and suggested corrections from the beginning to the end.

\section{REFERENCES}

Abate T, Shiferaw B, Menkir A, Wegary D, Kebede Y, Tesfaye K, Kassie M, Bogale G, Tadesse B, Keno T (2015) Factors that transformed maize productivity in Ethiopia. Food Security 7(5):965981

Abile T, Alemayehu G (2014). Corn-Root Boring White Grub and its Management, the Case of Ethiopia. African Journal of Basic \& Applied Sciences 6(3):50-56.

Abu T (2015). Grain and Feed Annual Report. Global agricultural information network report no ET-1503:01-14.

ACAPS (2017). AFRICA Fall Armyworm Outbreaks. ACAPS Thematic Report April 25, 2017.

ACAPS (2019). Ethiopian desert locust crisis impact overview. Briefing notes November 15, 2019. Start network pp. 1-4.

Ashenafi M (2010). Comparative analysis of maize-livestock innovation systems in Awassa, Bako and Ambo areas of Ethiopia. PhD Dissertation, Haramaya University. Unpublished document, Haromaya, Ethiopia.

Assefa F, Ayalew D (2019). Status and control measures of fall armyworm (Spodoptera frugiperda) infestations in maize fields in Ethiopia: A review . Cogent Food \& Agriculture 5: 1641902.

ATA (2014). Maize production, and productivity. Crop production Annual Report, Addis Ababa, Ethiopia.

Bekeko Z (2013). Epidemiology and molecular characterization of quantitative trait loci (QTLs) for resistance to common rust (Puccinia sorghi) and gray leaf spot (Cercospora zeae maydis) diseases of maize in Ethiopia. Journal of Genetic and Environmental Resources Conservation 1(3):185-196.

Bezuidenhout S, Nunkumar A (2017). Chemical control options for Fall armyworm in maize. Research \& Technology bulletin 17/09. PP. 01 03.

Christensen K, Harper B, Luukinen B, Buhl K, Stone D (2009). Chlorpyrifos Technical Fact Sheet; National Pesticide Information Center, Oregon State University Extension Services. http://npic.orst.edu/factsheets/archive/chlorp

Das TK, Sakhuja PK, Zelleke H (2010). Herbicide efficacy and nontarget toxicity in highland rainfed maize of Eastern Ethiopia. International Journal of Pest Management 56(4):315-325.

Ethiopian Agricultural Research Organization (EARO) (2001). Strategies and priorities for maize research. November 14, 2001. 
Addis Ababa, Ethiopia.

Ethiopian Institute of Agricultural Research (EIAR), Ambo College (Ethiopia), International Livestock Research Institute (ILRI), International Water Management Institute (IWMI), Association of Ethiopian Microfinance Institutions (AEMFI), Ministry of Agriculture and Rural Development (MoARD) (2010). Maize Value Chain Potential in Ethiopia: constraints and opportunities for enhancing the system. International food policy research institute (IFPRI) publication. pp. 02-40.

Food and Agriculture Organization (FAO) (2017). Fall Armyworm outbreak in African countries. The Food and Agriculture Organization of the United Nations Annual report 2016-2017. Pp 01-25.

Gemechu N, Sentayehu A, Leta T (2016). Review on Quality Protein Maize Breeding for Ethiopia. Journal of Biology, Agriculture and Healthcare 6(15): 2224-3208.

Harold M (2015). Cereal Crops: Rice, Maize, Millet, Sorghum, Wheat. The United Nations Economic commission for Africa Annual report, October 2015.

Kamrin MA (1997). Pesticide Profiles Toxicity, Environmental Impact, and Fate; Lewis Publishers: Boca Raton, FL. pp. 147-152.

Karanth S, Pope C (2000). Carbosylesterase and A-Esterase Activities during Maturation and Aging: Relationship to the Toxicity of Chlorpyrifos and Parathion in Rats. Toxicological Sciences 58:282289.

Kebede M, Gezahegne B, Benti T, Mossisa W, Yigzaw D, Assefa A (1993). Maize production trends and research in Ethiopia. Proceedings of the First National Maize Workshop of Ethiopia. Addis Ababa, Ethiopia pp. 142-154.

Mahuku G, Lockhart BE, Wanjala B, Jones MW, Kimunye JN, Stewart LR, Cassone BJ, Sevgan S, Nyasani JO, Kusia E, Kumar PL (2015). Maize lethal necrosis (MLN), an Emerging Threat to Maize-Based Food Security in Sub-Saharan Africa._Phytopathology 105(7):956965.
Midega AO, Jimmy O, Pittchara, John A, Girma W, Hailua, Z, Khana $R$ (2018). A climate-adapted push-pull system effectively controls fall armyworm, Spodoptera frugiperda (J. E. Smith), in maize in East Africa. Crop Protection 105(2018):10-15.

Misgana M, Yesuf E, Awoke T (2015). Evaluation of Maize Variety for Ear Rot (Fusarium graminearum) in South Omo Zone of Ethiopia. Journal of Plant Sciences 3(4):212-215.

Nicol J, Turner M, Coyne SJ, Nijs DL, Hockland LD, Tahna Maafi $Z$ (2011). Current Nematode Threats to World Agriculture. CIMMYT International Maize and Wheat Improvement Centre 39:21-34.

Prasanna B, Joseph M, Huesing E, Regina E, Virginia $M$ Peschke (2018). Fall Armyworm in Africa: A Guide for Integrated Pest Management, First Edition. Mexico, CDMX: CIMMYT.

Rosegrant MW, Msangi S, Ringler C, Sulser TB, Zhu T, Cline SA (2008) International Model for Policy Analysis of Agricultural Commodities and Trade (IMPACT): Model Description. International Food Policy Research Institute Washington DC.

Seyoum A, Taffesse P, Dorosh P, Sinafikeh A (2010). Crop Production in Ethiopia: Regional Patterns and Trends. IFPRI and EDRI journals. Ethiopia Strategy Support Program II (ESSP II) no 0016: 01-25.

The International Maize and Wheat Improvement Center (CIMMYT, 2015). Africa's Food Security Threatened by Deadly Maize Disease. Scientists, policymakers, seed companies and regulators joint conference. May 12 to 14, 2015.

Tsedaley B, Adugna G (2016). Detection of Fungi Infecting Maize (Zea mays L.) Seeds in Different Storages Around Jimma, Southwestern Ethiopia. Journal of Plant Pathology and Microbiology 7:338.

Foreign Agricultural Service (USDA) (2017). Drought could impact corn, srghum, and millet production in Ethiopia. Grain report number ET1709 pp. 5-7. 